\title{
PENDIDIKAN JARAK JAUH / PJJ SAAT WABAH COVID-19 MEMENGARUHI MOTIVASI BELAJAR MAHASISWA AKADEMI KEPERAWATAN HERMINA MANGGALA HUSADA
}

\author{
Ria Anugrahwati ${ }^{1}$, Junita Silitonga ${ }^{2}$ \\ ${ }^{1,2}$ Akademi Keperawatan Hermina Manggala Husada \\ E-mail: riaanugrahwatirusdin@gmail.com
}

\begin{abstract}
Abstrak
Penelitian ini bertujuan untuk mengidentifikasi Hubungan Pendidikan Jarak Jauh (PJJ) Saat Wabah Covid-19 terhadap Motivasi Belajar Mahasiswa Akademi Keperawatan Hermina Manggala Husada. Penelitian ini menggunakan desain survey cross sectional study pada 150 responden mahasiswa. Hasil penelitian menunjukkan karakteristik dari 150 responden sebagian besar $(95,3 \%)$ berjenis kelamin perempuan. Sebagian besar $(96,7 \%)$ responden berusia $15-20$ tahun. Terdapat hubungan yang bermakna antara Pendidikan Jarak Jauh dengan motivasi belajar mahasiswa di Akademi Keperawatan Hermina Manggala Husada Jakarta. Rekomendasi dari penelitian ini adalah perlunya komunikasi yang baik antara pembimbing akademik dengan mahasiswa terkait motivasi belajar secara PJJ dan perlunya membuat grup belajar agar mahasiswa tetap aktif di masa Covid-19 melalui grup online.
\end{abstract}

Kata kunci: covid-19, motivasi, PJJ

\begin{abstract}
This study aims to identify the Relationship of Distance Education (PJJ) during the Covid-19 Outbreak to Student Motivation of the Nursing Academy Hermina Manggala Husada. This study used a cross sectional study survey design on 150 student respondents. The results showed that the characteristics of the 150 respondents, mostly (95.3\%) were female. Most of the respondents (96.7\%) were 15-20 years old. There is a significant relationship between Distance Education and student learning motivation at the Hermina Manggala Husada Academy of Nursing, Jakarta. The recommendation of this study is the need for good communication between academic supervisors and students regarding learning motivation in PJJ and the need to create study groups so that students remain active during the Covid-19 period through online groups.
\end{abstract}

Keywords: Covid-19, motivation, distance Education

\section{Pendahuluan}

Pendidikan Jarak Jauh (PJJ) merupakan

proses belajar mengajar yang dilakukan secara jarak jauh melalui penggunaan berbagai media komunikasi (UU Perguruan Tinggi No. 12 tahun 2012, pasal 31). Akper Hermina Manggala Husada saat ini menerapkan sistem Pendidikan Jarak Jauh/ PJJ. Berbeda seperti pembelajaran dengan tatap muka di kelas.

Sistem Pendidikan jarak jauh memiliki beberapa karakteristik yaitu dosen dan mahasiswa tidak bertemu secara langsung, menggunakan media online melalui program
E-Campuz yang ada di Akper Hermina dan menggunakan aplikasi Zoom. Metode PJJ dilakukan sejak adanya wabah Corona virus disease 2019.

Akper melakukan PJJ dengan menggunakan E-Campuz dan Zoom meeting. Dari hasil wawancara beberapa mahasiswa bahwa didapatkan jika PJJ dengan E-Campuz mereka merasa kurang memahami pelajaran dikarenakan tugas tersebut tidak mendapatkan umpan balik sepenuhnya, sedangkan jika melalui Zoom meeting mereka mengatakan paham akan penjelasan dari dosen tetapi kuota yang cepat habis. Selama PJJ 
berlangsung, hanya $0,02 \%$ (6 mahasiswa dari 255 mahasiswa akper) yang terkadang tidak mengikuti PJJ dengan alasan signal susah serta kuota habis.

Mahasiswa PJJ harus mempertahankan keragaman sifat untuk menemukan keberhasilan dalam kuliah. Karakteristik unik yang dimiliki oleh mahasiswa Pendidikan jarak jauh adalah diikuti oleh semua usia. Simonson, et al. (2009) mengenali lingkungan Pendidikan yang akurat, sebelum pengetahuan dan gaya belajar mahasiswa sebagai indikator keberhasilan PJJ. Apabila mahasiswa dalam PJJ menginginkan kesuksesan harus memiliki manajemen waktu, motivasi diri dan kemampuan berkomunikasi untuk kebutuhan mereka.

Menurut Direktorat Tenaga Kependidikan, motivasi sangat penting dalam belajar karena motivasi dapat mendorong mahasiswa mempersepsi informasi dalam bahan ajar. Sebagus apa pun rancangan bahan ajar, jika mahasiswa tidak termotivasi maka tidak akan terjadi peristiwa belajar karena mahasiswa tidak akan mempersepsi informasi dalam bahan ajar tersebut. Dengan fenomena diatas maka penulis tertarik untuk melihat adakah hubungan PJJ saat wabah COVID-19 dengan Motivasi belajar mahasiswa.

\section{Tinjauan Teori}

\section{Pendidikan Jarak Jauh/PJJ}

Karakteristik utama dari pembelajaran jarak jauh adalah adanya keterpisahan, baik keterpisahan secara fisik, psikologis dan komunikasi, antara pengajar dan peserta belajarnya, sebagaimana yang dikemukakan Moore (1983) keterpisahan jarak antara siswa dan guru dalam Pendidikan jarak jauh tidak hanya dipandang dari segi jarak fisik dan geografis saja melainkan harus dilihat sebagai jarak komunikasi dan psikologis yang disebabkan karena keterpisahan antara mahasiswa dan guru. Keterpisahan tersebut merupakan jarak transaksi yang terjadi dalam proses pembelajaran sehingga diperlukan formula untuk menjembatani batas transaksi dalam pembelajaran tersebut, karena jarak transaksi mengakibatkan perbedaan persepsi mengenai konsep yang disampaikan.

\section{Konsep Motivasi Belajar}

Motivasi menurut Utsman Najati yaitu kekuatan penggerak yang membangkitkan aktivitas pada seseorang dan menimbulkan tingkah laku serta mengarahkan pada tujuantujuan tertentu. Motivasi dalam belajar, memandang motivasi dan reward sebagai hal yang kurang penting dalam belajar . motivasi hanyalah menimbulkan variasi respons pada individu dan bila dihubungkan dengan hasil belajar, motivasi tersebut bukan instrumental dalam belajar (Ghuthrie).

Sedangkan menurut Sardiman motif dapat diartikan sebagai daya upaya yang mendorong seseorang untuk melakukan sesuatu. Motif dapat dikatakan sebagai penggerak dari dalam dan di dalam subjek untuk melakukan aktifitas-aktifitas tertentu demi mencapai 
suatu tujuan. Bahkan motif dapat dikatakan sebagai suatu kondisi intern. Berawal dari kata motif, maka motivasi dapat diartikan sebagai daya penggerak yang telah menjadi aktif. Motif menjadi aktif pada saat-saat tertentu, terutama bila kebutuhan untuk mencapai tujuan sangat dirasakan atau mendesak.

\section{Metodologi}

Penelitian ini merupakan penelitian deskriptif yaitu metode penelitian yang dilakukan dengan tujuan untuk membuat gambaran atau deskriptif tentang suatu keadaan secara objektif (Notoatmodjo, 2012).

Desain penelitian ini menggunakan pendekatan Cross Sectional yang bertujuan mengetahui hubungan Pendidikan jarak jauh. Variabel terikat yaitu motivasi belajar dan variabel kontrol adalah karakteristik individu mahasiswa yang meliputi: jenis kelamin, usia dan tempat tinggal.

Populasi dalam penelitian ini adalah seluruh mahasiswa di Akper sebanyak 255 orang mahasiswa. Penentuan jumlah sampel dengan menggunakan tehnik sampling total sampling yang dibatasi dengan kriteria-kriteria tertentu. Adapun kriteria sampel antara lain; (1) kriteria inklusi; bersedia menjadi responden yang dibuktikan dengan kesediaan menandatangani informed consent. Sedangkan (2) kriteria eksklusi; semua mahasiswa yang saat dilakukan penelitian sedang tidak berada di tempat karena sakit.
Penelitian ini dilaksanakan di Akper Hermina Manggala Husada mulai dari April sampai Juni 2020. Total jumlah sampel dalam penelitian ini 171 responden. Alat pengumpulan data dilakukan dengan menggunakan lembar kuesioner. Lembar kuesioner terkait karakteristik responden yang terdiri dari jenis kelamin, dan usia.

Kuesioner berisi tentang hubungan PJJ saat wabah covid-19 terhadap motivasi belajar mahasiswa yang terdiri dari 4 pertanyaan dengan menggunakan skala likert. Dan kuesioner terkait dengan motivasi belajar mahasiswa di Akper Hermina Manggala Husada yang terdiri dari 15 pernyataan dengan menggunakan skala likert.

\section{Hasil}

Karakteristik Responden pada penelitian ini dapat di lihat pada Tabel 1.

Tabel 1. Karakteristik Responden

\begin{tabular}{lcc}
\hline \multicolumn{1}{c}{ Karakteristik } & Jumlah & $(\boldsymbol{\%})$ \\
\hline Usia : & & \\
$15-20$ tahun & 145 & 96,7 \\
$21-25$ tahun & 5 & 3,3 \\
& & \\
Motivasi belajar & & \\
Kurang baik & 7 & 4,7 \\
Baik & 143 & 95,3 \\
\hline
\end{tabular}

Tabel 1 menunjukkan bahwa proporsi terbesar berusia 15-20 tahun sebanyak 145 responden (96,7\%). Dan proporsi terbesar motivasi belajar baik sebanyak 143 responden $(95,3 \%)$. 
Table 2. Hubungan motivasi mahasiswa dengan PJJ

\begin{tabular}{lll}
\hline \multicolumn{1}{c}{ Variable } & \multicolumn{1}{c}{ Jumlah } & $(\boldsymbol{\%})$ \\
\hline Pembelajaran jarak jauh: & & \\
E-Campuz & 62 & 41,3 \\
Zoom Meeting & 88 & 58,7 \\
& & \\
Jenis kelamin : & 7 & 4,7 \\
Laki-laki & & \\
Perempuan & 143 & 95,3 \\
\hline
\end{tabular}

Pada tabel 2. menunjukkan bahwa proporsi terbesar pembelajaran jarak jauh menggunakan Zoom Meeting mempengaruhi motivasi belajar sebanyak 88 responden $(58,7 \%)$.

Proporsi terbesar pada jenis kelamin perempuan sebanyak 143 responden $(95,3 \%)$.

Table 3. Hubungan pembelajaran jarak jauh dengan motivasi belajar mahasiswa di Akper Hermina Manggala Husada.

\begin{tabular}{lcccc}
\hline \multirow{2}{*}{$\begin{array}{c}\text { Variable } \\
\text { independen }\end{array}$} & \multicolumn{3}{c}{ Motivasi belajar } \\
\cline { 2 - 5 } & \multicolumn{2}{c}{ Kurang } & \multicolumn{2}{c}{ Baik } \\
\cline { 2 - 5 } & Jumlah & $\mathbf{( \% )}$ & Jumlah & $\mathbf{( \% )}$ \\
\hline PJJ : & & & & \\
E-Campuz & 39 & 62,9 & 23 & 37,1 \\
Zoom meeting & 21 & 23,9 & 67 & 76,1 \\
\hline
\end{tabular}

Berdasarkan hasil uji statistik pada tabel 4.3 diperoleh bahwa dari 62 responden melakukan PJJ menggunakan E-Campuz memiliki motivasi belajar yang kurang berjumlah 39 responden $(62,9 \%)$, sedangkan PJJ menggunakan Zoom meeting dari 88 responden memiliki motivasi belajar yang baik berjumlah 67 responden $(76,1 \%)$.

Didapatkan nilai $P v=0,000$ maka dapat disimpulkan ada hubungan yang signifikan antara PJJ terhadap motivasi belajar mahasiswa. Hasil analisis juga diperoleh nilai
OR $($ Odd Ratio $)=5,410(95 \%$

CI. 2,65711,017) artinya PJJ mempengaruhi motivasi berpeluang 5,410 kali.

\begin{tabular}{|c|c|c|c|c|}
\hline \multirow{3}{*}{$\begin{array}{c}\text { Variable } \\
\text { independen }\end{array}$} & \multicolumn{4}{|c|}{ Motivasi belajar } \\
\hline & \multicolumn{2}{|c|}{ Kurang } & \multicolumn{2}{|c|}{ Baik } \\
\hline & Jumlah & $(\%)$ & Jumlah & $(\%)$ \\
\hline Jenis kelamin & & & & \\
\hline Laki-laki & 3 & 42,9 & 4 & 57,1 \\
\hline Perempuan & 57 & 39,9 & 86 & 60,1 \\
\hline
\end{tabular}

Berdasarkan hasil uji statistik pada tabel 4 diperoleh bahwa dari 7 responden yang jenis kelamin laki-laki sebagian besar motivasi belajar baik berjumlah 4 responden $(57,1 \%)$ dan yang kurang motivasi belajar berjumlah 3 responden $(42,9 \%)$.

Dari 143 responden yang jenis kelamin perempuan sebagian besar motivasi belajar baik berjumlah 86 responden $(60,1 \%)$ dan yang kurang motivasi belajar berjumlah 57 responden $(39,9 \%)$.

Didapatkan nilai $P=1,000$ maka dapat disimpulkan tidak ada hubungan yang signifikan antara jenis kelamin terhadap motivasi belajar mahasiswa (pvalue $>0,05$ ).

Berdasarkan hasil uji statistik pada tabel 5 diperoleh bahwa dari 145 responden yang usia 15-20 tahun sebagian besar motivasi belajar baik berjumlah 88 responden $(60,7 \%)$ dan yang kurang motivasi belajar berjumlah 57 responden $(39,3 \%)$. 
Table 5. Hubungan usia dengan motivasi belajar mahasiswa di Akper Hermina Manggala Husada Jakarta

\begin{tabular}{lcccc}
\hline \multirow{2}{*}{$\begin{array}{l}\text { Variable } \\
\text { independen }\end{array}$} & \multicolumn{4}{c}{ Motivasi belajar } \\
\cline { 2 - 5 } & \multicolumn{2}{c}{ Kurang } & \multicolumn{2}{c}{ Baik } \\
\cline { 2 - 5 } & Jumlah & $\mathbf{( \% )}$ & Jumlah & $\mathbf{( \% )}$ \\
\hline Usia : & & & & \\
15-20 tahun & 57 & 39,3 & 88 & 60,7 \\
21-25 tahun & 3 & 60,0 & 2 & 40,0 \\
\hline
\end{tabular}

Dari 20 responden yang usia 21-25 tahun sebagian besar motivasi belajar kurang berjumlah 3 responden $(60,0 \%)$ dan yang ada motivasi belajar berjumlah 2 responden (40,0\%). Didapatkan nilai $P=0,642$ maka dapat disimpulkan tidak ada hubungan yang signifikan antara usia terhadap motivasi belajar mahasiswa (pvalue $>0,05$ ).

Berdasarkan pemodelan lengkap yang mencakup variabel independen (motivasi belajar) dan kandidat confounding (jenis kelamin, usia). Selanjutnya dilakukan pengeluaran variabel yang tidak signifikan secara bertahap satu persatu, dimulai dari variabel interaksi yang $p$ value-nya terbesar.

Berdasarkan pemodelan akhir, maka hasil penelitian ini menunjukkan bahwa mahasiswa melakukan PJJ menggunakan Zoom Meeting memiliki motivasi belajar yang baik dibandingkan menggunakan E-Campuz. PJJ mempengaruhi motivasi berpeluang 5,410 kali. Berdasarkan hasil uji statistik diperoleh bahwa dari 88 responden yang melakukan PJJ menggunakan Zoom Meeting memiliki motivasi belajar yang baik berjumlah 67 responden $(76,1), \quad$ sedangkan PJJ menggunakan E-Campuz memiliki motivasi belajar baik berjumlah 23 responden $(37,1 \%)$.

\section{Pembahasan}

Hasil uji statistik menunjukkan ada hubungan yang signifikan antara PJJ dengan motivasi belajar mahasiswa. Jumlah responden yang bersedia mengisi kuesioner penelitian sebanyak 150 responden.

Hasil penelitian ini sejalan dengan penelitian Anra (2003) diperoleh kesimpulan bahwa terdapat hubungan positif antara motivasi berprestasi dengan kualitas lulusan D-II PGSD Universitas Terbuka. UT merupakan institusi Pendidikan tinggi yang menerapkan system PJJ yang didirikan dengan tujuan memberikan kesempatan yang lebih luas bagi mereka yang ingin melanjutkan pendidikan tinggi tetapi tidak dapat bergabung pada institusi tatap muka. Makin tepat motivasi belajar di UT yang diberikan maka akan semakin berhasil pula mahasiswa tersebut dalam belajar di UT.

Menurut pendapat Cecco (1996) motivasi itu bertalian dengan belajar. Dimyati \& Mudjiono (1999) menyetakan bahwa motivasi belajar merupakan segi kejiwaan yang mengalami perkembangan yang terpengaruh oleh kondisi fisiologis dan kematangan psikologi siswa. Berdasarkan pendapat para ahli tentang motivasi belajar maka dapat diambil kesimpulan bahwa motivasi belajar berkaitan dengan proses belajar. Motivasi dalam belajar sangat diperlukan karena dapat 
meningkatkan semangat peserta didik untuk belajar. Hal ini dapat diamati dari banyaknya kenyataan, bahwa motivasi seorang siswa menjadi begitu tinggi ketika ia sebelumnya sudah memiliki cita-cita.

Hasil analisis peneliti didapatkan bahwa PJJ menggunakan Zoom Meeting lebih efektif untuk pembelajaran dan motivasi belajar mahasiswa baik dibandingkan dengan menggunakan E-Campuz saja. Karena dengan media Zoom Meeting mahasiswa dapat melihat langsung slide materi, dan chat online melalui perangkat lunak. Jadi ketika ada hal yang belum dipahami, mahasiswa bisa langsung bertanya kepada dosen. Dosen juga bisa langsung memberikan respon positif kepada mahasiswa ketika saat diskusi aktif. Sehingga membuat motivasi belajar mahasiswa meningkat. Dengan media inipun mahasiswa dapat melakukan presentasi. Tetapi teradapat kekurangan dalam aplikasi ini yaitu kuota akan cepat habis dan signal yang naik turun. Penggunaan aplikasi ECampuz juga terdapat beberapa kelebihan yaitu mahasiswa bisa mengumpulkan tugas sesuai waktu yang diberikan, melihat nilai dari tugas tersebut, dapat mengakses materi yang diberikan dosen dan dapat melakukan diskusi. Serta kemudahan dalam penggunaan aplikasi E-Campuz membuat mahasiswa tertib dalam pengumpulan tugas. Maka peneliti mengambil kesimpulan bahwa motivasi belajar mahasiswa secara PJJ saat wabah COVID-19 tetap ada karena didukung oleh beberapa aplikasi yang mudah untuk digunakan walaupun memiliki kekurangan masing-masing.

\section{Kesimpulan}

Berdasarkan hasil penelitian dan pembahasan tentang Hubungan Pendidikan Jarak Jauh (PJJ) Saat Wabah Covid-19 terhadap Motivasi Belajar Mahasiswa Akademi Keperawatan Hermina Manggala Husada, dapat disimpulkan sebagai berikut:

1. Karakteristik dari 150 responden sebagian besar $(95,3 \%)$ berjenis kelamin perempuan. Sebagian besar $(96,7 \%)$ responden berusia 15-20 tahun.

2. Terdapat hubungan yang bermakna antara PJJ dengan motivasi belajar mahasiswa di Akademi Keperawatan Hermina Manggala Husada Jakarta $(\mathrm{Pv}=0,000)$.

\section{Saran}

Bagi pendidikan keperawatan :

1. Perlunya komunikasi yang baik antara pembimbing akademik dengan mahasiswa terkait dengan motivasi belajar secara PJJ

2. Perlunya membuat grup belajar agar mahasiswa tetap aktif di masa Covid-19 melalui grup online

\section{Ucapan Terima Kasih}

Penelitian ini terselesaikan berkat bimbingan dorongan arahan dari pembimbing untuk itu 
perkenankanlah peneliti menyampaikan terima kasih kepada yang terhormat :

1. Yulisar Khiat, SE.,MARS selaku Ketua Yayasan Bhakti Husada Jaya

2. Direktur dan seluruh staf Akper Hermina dalam memberikan dukungan

3. Semua pihak yang tidak dapat disebutkan satu persatu yang telah mendukung terselesaikannya penelitian ini dengan baik.

\section{Referensi}

Buxbaum, Sari (2004) Library Service Perpustakaan Virtual untuk Kuliah Bisnis Sistem Jarak Jauh. Jakarta: Raja Grafindo Perkasa

Direktorat jenderal pencegahan dan pengendalian penyakit. (2020). Pedoman pencegahan dan pengendalian coronavirus disease (covid-19). Jakarta : Kementrian kesehatan republik Indonesia.

Hamalik, Oemar (1993). Sistem Pembelajaran Jarak Jauh. Bandung: Trigenda Karya

Hanoroun. (2010). Model Pembelajaran ARCS. Online

Harun, N.F., Khairiyah Mohd Yusof, Mohammad Zamry Jamaludinc, Syed Ahmad Helmi Syed Hassand. 2012. Motivation in Problem-based Learning Implementation. Journal ProcediaSocial and Behavioral Sciences 56 (2012)

Heldavidson ,First Covid-19 case happened in November, China government records show - report2020, diakses dari https://www.theguardian.com/world/20 20/mar/13/first-covid-19-casehappened-in-november-chinagovernment-records-show-report Pada 20 Maret 2020
Hodges, C. (2004). Designing to motivated : Motivational Techniques to Experiences. The Journal of Interactive Online Learning

Kementerian Kesehatan Republik Indonesia. COVID-19. 2020 [cited 2020 Apr 5].

Moore, Michael (1983). A Theory of Apartness and Autonomy dalam Keegan, Desmond Six Distance Education Theorist. ZIFF : Hagen

NIH, New coronavirus stable for hours on surfaces SARS-CoV-2 stability similar to original SARS, 2020, diakses dari virushttps://www.sciencedaily.com/ releases/2020/03/200317150116.htm pada 20 Maret 2020

Perdatin. (2020). Buku pedoman penanganan pasien kritis covid-19 Versi 1.

Rachael D'amore, Coronavirus: Where did it come from and how did we get here?,2020, diakses dari https://globalnews.ca/news/6682629/cor onavirus-how-did-it-start/ Pada 20 Maret 2020

Wang C, Horby PW, Hayden FG, Gao GF. A novel coronavirus outbreak of global health concern. Lancet. 2020;395:4703.

CDC (Centers for Disease Control and Prevention), One Health, diakses dari https://www.cdc.gov/onehealth/basics/i ndex.html pada 17 Maret 2020

https://eprints.uny.ac.id/8469/5/lampiran\%20$\% 2008502244024 . p d f$

http://repository.fkip.unja.ac.id/file?i=eIgV42 olkM8hY4MxDaexN4HrkoewtuV1frF W3IAU8wI 